\title{
One More Coincide Between Architects and Laypersons on The Aesthetics of Zaha Hadid's Buildings
}

\author{
Berivan Özbudak Akça ${ }^{1 \odot}$, Ebru Erdoğan² \\ ${ }^{1}$ Assist. Prof. Dr., Faculty of Architecture, Department of Architecture, Dicle University, Diyarbakir, Turkey. (Principal contact \\ for editorial correspondence) Email: ybbudak@gmail.com \\ 2 Assoc. Prof. Dr.,Faculty of Fine Arts, Department of Interior Architecture and Environment Design, Selcuk University, Konya, \\ Turkey. Email: interarchebru@hotmail.com
}

\begin{abstract} Purpose

This study focuses on the subject of environmental aesthetics and aims to identify the differences and similarities that emerge in the general aesthetic evaluations toward the individual style, particularly examining the physical and connotative meanings in the buildings by Zaha Hadid. The study further seeks to understand how individual style fosters aesthetic awareness or common perceptions on a universal level without causing a cultural difference.

Design/Methodology/Approach

A survey was conducted to understand the visual aesthetic evaluations of architects and laypersons over 16 buildings of Hadid-an architect who managed to develop her own individual style. The visual images created were evaluated in terms of sensorial and physical concepts in order to understand whether there was a common language by evaluating the aesthetic perceptions of subjects with different backgrounds, and to reveal the effect of individual style in forming a universal tongue. Descriptive statics, correlation analysis and independent $t$ test were performed to conduct the evaluations.

Findings

According to analysis results, the rhythm and organic lines of a building are the most significant elements for building façades and masses in aesthetic evaluations. In addition, no significant differences regarding the dimensions of "liking", "ornate", "attractive", "meaningful" and "warm" were found between the groups.

\section{Research Limitations/Implications}

The survey was conducted between two different subject groups; architects and laypersons. Specific parameters related to the sensorial concepts of the buildings were used. These parameters included the concepts of liking, pleasant, complex, familiar, meaningful, ornate and warm, while for the physical characteristics of the buildings, the concepts of regular/ irregular, full/ empty, rhythmic/ arrhythmic, soft/ hard, meaningful/ meaningless and symmetric/asymmetric were used.

Originality/Value

This study is significant insofar as it is among the rare research studies that found there to be no differences between architects and laypersons but rather, similarities between them.
\end{abstract}

Keywords: Architect, experimental aesthetic, individual style, layperson, , Zaha Hadid 


\section{INTRODUCTION}

The concept of aesthetics, which evokes intellectual, artistic and/or spiritual fascination, is a social necessity. Aesthetic needs are categorized under two groups, namely, beauty and individual expression. The expectations people have of an architectural structure include sheltering, security, comfort, socialization, self-expression and aesthetics, and they desire the building of spaces that they can admire, both physically and aesthetically, and where they can feel sense of peace and happiness. Therefore, a thorough analysis of the target audience should be performed in order to arrive at solutions that are capable of meeting the intended audience's needs and of being visually appealing. In addition, aesthetic differences are the qualities that separate architectural building from one another and serve to ensure that the spaces are easily remembered. Aesthetic criteria vary by personal factors, such as culture and education. However, the aesthetic criteria to be considered in the formation of the internal and external atmosphere of a structure include different factors such as form (holistic form, form of components), detail, axis, structure (structural solution of the form), materials, color, scale, rhythm emphasis, light, harmony, green areas, environmental areas, urban aesthetics, height and density of buildings, their stylistic compatibilities, and landscape.

The human brain is a mechanism of perception, cognition and behavior. The main theme of human-environment studies involves all the behavioral components of the subject, which are formed by receiving stimuli through the senses in the perception process, processing these stimuli during the cognitive process, making sense of them through evaluation and understanding, and then directing the behaviors accordingly by creating images. These studies, which are interdisciplinary in nature, aim to systematically review the complex relationships between human nature and environmental variables and to assess their mutual interaction (Rapoport, 1977). From this point of view, environmental-behavioral research, which deals with the relationships between human nature and environmental variables, involves the working area of architects, who design the living environment, as this type of research examines and details human-environment interaction, behaviors, harmony and disharmony. In addition, environmental aesthetics, defined as the perceived quality of the environment, is considered an important component of environmental quality. Aesthetic evaluation of the environment gains importance as an element that affects the environmental preferences of individuals and shapes spatial behavior and has an inclusive feature as it deals with different scales of field (Nasar, 2008; Nasar, 1989a). In this sense, the research is used in aesthetic evaluations to see the meanings and effects of the products created by designers.

Meaning is a critical concept for environmental perception. It is one of the most significant determinants of behavior, and as such, concerns emotions (Abercrombie, 1984). An architectural structure should carry 
meaning within the environment it is located. Research in the fields of environmental psychology, sociology and environmental aesthetics indicates that architectural meaning has gained significance in creating an environment that can be perceived, felt and used satisfactorily, and that meaning is integrated with usage and style (Aydınl, 1993). In the field of architecture, meaning is expressed both cognitively and affectively, with their mutual interaction with the buildings being described as knowing, understanding and liking/disliking, respectively. The first realization of the world occurs through perception (Schulz, 1965), and sensation and perception of beauty, or the formation of aesthetic sense, requires visual perception first. The components have to first be perceived before they are organized and evaluated in designs (Rapoport, 1980). The product of perception at the sensory level, the form in any sensory environment (smell, spiritual sensation, sound, etc.), and the consciousness of these forms are always charged with a meaning. However, this meaning does not need to be found with a word in mind (Erzen, 2006). Architectural meaning has two different dimensions, depending on the interpretation of the relationships between the people who form, use, live and assess the architectural environment. In the first dimension, the architectural product exists with the meaning assigned by the architect, and it is interpreted through his/her style. In the second dimension, once the architectural product is created and revealed, it is now open to interpretation and that they gain meanings through the interpreters. The evaluation, which can be either positive or negative as a result of the interaction between architecture and the environment, is subjective, as it is subject-based and individual. However, it also reveals a structure that is naturally obtained and objectified, partially through the partnerships seen in the separate, specific decisions and experiences effectuated as a result of coexistence. Therefore, unchangeable objective values and decisions emerge against these subjective characteristics of evaluation (Şentürer, 1995). Architecturally-designed products can be evaluated from many aspects, including economic, technological, climatic and ethical. As these perceptions are insufficient in terms of reaching the essence of architecture, that is, the content of the architectural product, they should be evaluated from an aesthetic point of view in order to understand the relationship between the architectural values and meanings, and nature. New modes, styles, trends and manners have emerged for the purpose of creating better stylistic and aesthetic forms (Şentürer, 1995).

\section{Style and Meaning}

Style is a way of expressing artistic works and is used to characterize different people, times and regions (Greene, 1940). The elements constituting the external appearance of an object are generally judged by the internal structure of the same object. In this sense, style can be viewed as a concept, rather than as an object. Moreover, style is the recognition 
of the quality shared among many elements; quality, on the other hand, is related to a structure on a scale smaller than that of the elements of different qualities (Smith, 1981).

A style is historically determined on the basis of the distinct characteristics of products manufactured by an individual (individual style, e.g. Van Gogh style) or a group (group style, e.g. Prairie style) in certain geographical areas (regional style) or certain periods (era style, e.g. Renaissance style). If there is a series of common characteristics in many objects designed by the same person, that series then represents an individual style (Chan, 2000), while if there is series of common characteristics seen in objects designed by a group of designers, that series then represents a group style. Similarly, a collection of series symbolizes regional and periodical styles (Jencks 1977, 1980). According to Beardsley, the group characteristics of a product should include a particular set of stylistic features (Beardsley, 1979). If a group of characteristics is repeated in a group of products, a style emerges. In other words, common characteristics of a product group characterize a style (Ackerman, 1963). Schapiro states that individual style is an unchangeable form, with invariant elements, characteristics and expressions, which means that style emerges from the features and forms of architectural products characterized by repetitive elements, qualities and expressions. In addition, common characteristics are also related to form elements, form relations and form properties (Schapiro, 1961). Basically, in interpreting the characteristics of products, research has focused on exploring vernacular and temporal styles and group or regionrelated styles in order to understand how these products have been developed, and to identify the development of their function from social, cultural, political and psychological aspects (Erdoğan, 2010). Put more simply, researchers have interpreted how style is defined and manifested in periodic, regional and vernacular dimensions.

A style emerges in many different ways and is characterized by many factors, including culture, tradition, social life, technology and physical environment. Design and production phases form style, while human cognition creates and influences it (Erdoğan et al., 2010a, 2010b). Aesthetic perception within and among society's changes over time. However, there has always been an aesthetic approach that has been dominant in certain periods and environments (Şentürer, 1995). Architects or designers are influenced by the aesthetic aspect of their culture when creating styles that are capable of meeting usage-related requirements by utilizing the technical opportunities and materials of the era. Therefore, it is possible to see the same aesthetic approach in the structures of a certain period and society, even if they were designed by different architects and designers (Şentürer, 1995). The works of Zaha Hadid, who changed this concept and pushed its boundaries, belong to no specific time (timelessness), have fluent forms, use free forms, reflect costly designs requiring advanced technology and utilizes the virtual 
environment in designs. With these works, Zaha Hadid has created her own "individual style".

The detection of a style by an observer reflects denotative meaning, while liking a style reflects connotative meaning. The denotative and connotative meaning of a style varies by individual experiences (frequency of realizing that style) and building type (Schulz, 1965). This study aims to uncover the denotative meanings in the works by Zaha Hadid, an architect with a dominant individual style, and to present the connotative meanings generated by the subjects. In short, it aims to specify the denotative features of Zaha Hadid's buildings and their effects on subjects. The similarities and differences in perception between architects and the public in terms of the aesthetic evaluation (architectural evaluation criteria) performed will be presented. In this way, it can be observed what kind of aesthetic difference or similarity will be occurred by an individual style without cultural differences on a universal level.

\section{LITERATURE REVIEW}

Environmental aesthetics constitute the sub-branch of environmental psychology. Studies on experimental aesthetics were initiated by Gudmund Smithed in 1967 (Sandström, 1973) and continued to be carried out by Krampen (1978), Maalqe (1973) and Sanoff (1974). The studies in this field were later compiled and popularized by Rapoport (1980) and Nasar (1989a, 1989b). The aims behind environmentbehavior studies are to form spaces based on user preferences and to increase user satisfaction. Architects' creation of designs that met users' spatial expectations would help to generate a common language. Lang (1987) argued that the implementation of an approach that examines the aesthetic values adopted and enjoyed by users, where these values from both the artistic community and the public would merge at certain points, would be highly significant. Many types of research about experimental aesthetics have been conducted to investigate various aspects of buildings and cities to ensure user satisfaction Sánchez-Pantoja, Vidal and Pastor (2018), Amer and Attia (2019) (Stanislav and Chin, 2019). Although the literature includes many studies examining the different views and perceptions of architects and laypersons (Hershberger, 1969, 1988; Canter, 1969; Kaplan, 1974; İmamoglu, 1979; Groat, 1982; Devlin and Nasar, 1989; Erdogan et al., 2010a; Erdogan et al., 2010b; Nasar, 1989; Nasar and Kang, 1989; Devlin, 1990; Nasar and Purcell, 1990; Purcell, 1995; Hubbard, 1996; Purcell et al., 1998; Imamoglu, 2000; Gifford et al., 2000; Gifford et al., 2002; Brown and Gifford, 2001; Fawcett et al., 2008), only a limited number of studies have indicated there to be similar views between these two groups (Kunawong, 1986; Kuller, 1973; Özbudak et al., 2015). A number of studies have evaluated whether the meanings imposed by the architects and laypersons on to buildings matched with the names assigned to buildings and have assessed the spatial elements, regulations and power factors of various buildings 
(Hersberger 1969, 1988). Other studies have examined this difference in meaning with regard to the concepts and style perceptions in architecture (Groat, 1982). Sadalla \& Sheets (1993), in their study, discussed the symbolism concept in conjunction with the use of materials applied to the external layer of a building (Sadalla \& Sheets 1993). Nasar aimed to determine how laypersons arrived at the connotative meanings from different building styles and how these meanings changed in relation to socio-demographic qualities. In Nasar's study, the concepts of sincerity and status were used to perform the evaluation, and users were asked about these concepts after a scenario was formed (Nasar, 1989). For example, certain characteristics, such as height, rectangularity and color, can be easily measured (Benedikt, 1979), but features like complexity, protection, compatibility and style are more abstract parameters and operate at a higher level (Gifford et al., 2000). The results of these studies have been translated into general designing principles for architects and designers (Weber et al., 2002). There is a practice often studied by architects but rarely examined from a psychological perspective that has a potentially significant impact on the architectural design process. Architectural elements, such as walls, ceilings, roofs, columns and ladders, are variables that are specific to architectural design and as such, are simultaneously organized to ensure functional and aesthetic harmony. The assumption here is that certain geometric combinations of these elements captivate the attention of the spectators in a way that agrees with the architects' intentions (Weber et al., 2002). In the study by Kunawong (1986), architects and laypersons were compared with regards to their views toward architecture environments, and the nature of the difference between the two groups was examined. As part of this said study, a model involving five dimensions, namely, order, simplicity, uncertainty, innovation and power, all of which are based on visual stimulation and evaluation, was developed to predict and explain visual satisfaction. The results from the application of this model showed there to be no differences between architecture students and laypersons. Designs formed by taking into consideration the related variables could be adopted and understood by the public. In the study by Kuller (1973), comparisons were made between groups with different levels of prior knowledge; 8-factor (expensive, simple style, satisfaction, open, picturesque, mixed colors, masculine and normal) evaluation was found to be similar between the groups. Another study discusses how associative meaning, an input to the design, is perceived by architects and laypersons. This study was conducted in two phases. The study was carried out in two phases. In the first phase the mean values of the groups were calculated. The images that had matching views and meaning were determined, and the data related to these images were obtained. In the second stage, the method observed in the Lens Model was used to identify the overlapping images and data in order to reveal the common interpretations regarding the overlapping. The main objective of this study is to contribute to the efforts made to create lasting environments 
by exploring the similarities in perception between architects and laypersons and the points at which these perceptions intersect, as opposed to determining one-sided satisfaction, where architects alone must ensure that the public accepts their ideas. The feature of the study indicating that "common interpretations were made in the overlap between the images and meanings", is highly significant insofar as it facilitated determination of a common cognitive concept between both groups for the first time as well as insight into which physical components this cognitive concept is based (Özbudak Akça et al., 2015). In addition to these studies, there are also studies investigating the causable relationship of visual perception in parametric designs. In the study conducted by Basu and Ghosh (2018), it was investigated how some characteristic formal expressions that create striking visual interest affect visual perception, in designs made using parametric modeling techniques. This study, by combining parametric design and visual perception in a holistic way, offers a direction to the future framework that makes the design process more efficient, effective, optimum, rational and resource-saving, making the world a better place to live.

One of the main reasons behind the research on architects and laypersons is that the information obtained can be used by architects to predict public response, and in turn, public satisfaction with the creative products of architects will be increased (Hershberger and Cass, 1988). This study examined environmental aesthetics and aimed to identify the differences and similarities that emerge in the general aesthetic evaluation toward individual style, and to reveal the visual-aesthetic evaluations of the participants (architects-laypersons) in terms of the buildings created by an architect.

\section{METHOD}

A survey was administered to determine the participants' views and visual-aesthetic evaluations on the buildings created by Zaha Hadid and to understand what kind of aesthetic difference or similarity will be formed with an individual style at the universal level.

\section{Participants}

The survey was conducted with two different subject groups, one including architects educated in designs, and the other including laypersons with a bachelor's degree (with no design-related courses). A total of 98 surveys, equally divided between the two groups, were administered. The participants were randomly selected, and efforts were made to interview an equal number of men and women. Of the participants, 59.2\% $(n=58)$ were female and $40.8 \%(n=40)$ were male, $61.2 \%(n=60)$ were between the ages of 20 and 27, 7.1\% $(n=7)$ between the ages of 35 and 40 , and $11.2 \%(n=11) 41$ years of age and over. 


\section{Survey Design}

The survey included three phases. The first phase included questions on the participants' demographic information. The second phase included questions related to the participants' general aesthetic evaluations of Zaha Hadid's buildings. In the third phase, the sensory effects of Hadid's buildings were asked. Specific parameters related to the sensory effects of the buildings were used. These parameters included the concepts of liking, pleasant, complex, familiar, meaningful, ornate and warm, while for the physical characteristics of the buildings, the concepts of regular/ irregular, full/ empty, rhythmic/ arrhythmic, soft/ hard, meaningful /meaningless and symmetric/asymmetric were used. The participants were asked to rate each building on a 7-point Likert type scale (7 as the highest score, 1 as the lowest) according to the standards they personally applied for general aesthetic evaluations and understanding of the sensory effects of buildings. The two participating groups were informed about how to perform evaluations for each image, and any questions they had were answered accordingly.

\section{Images Used in the Study}

The subjects were shown 16 different images of Zaha Hadid buildings. Hundreds of building samples were compiled from different architecture journals, books and internet sites for the purpose of determining the visuals to be used in the survey, and an image bank was formed. The images selected for the study were not limited by their functions but rather, formed according to the parameters related to the emotional and physical effects of the building and to the criteria that they had no different architectural styles and showed no similarities. The images were all presented in the same sizes on A5 paper with good quality in order to prevent the presentation of the images from affecting the participants' preferences. The images used in the study were shown in Figure 1 below.

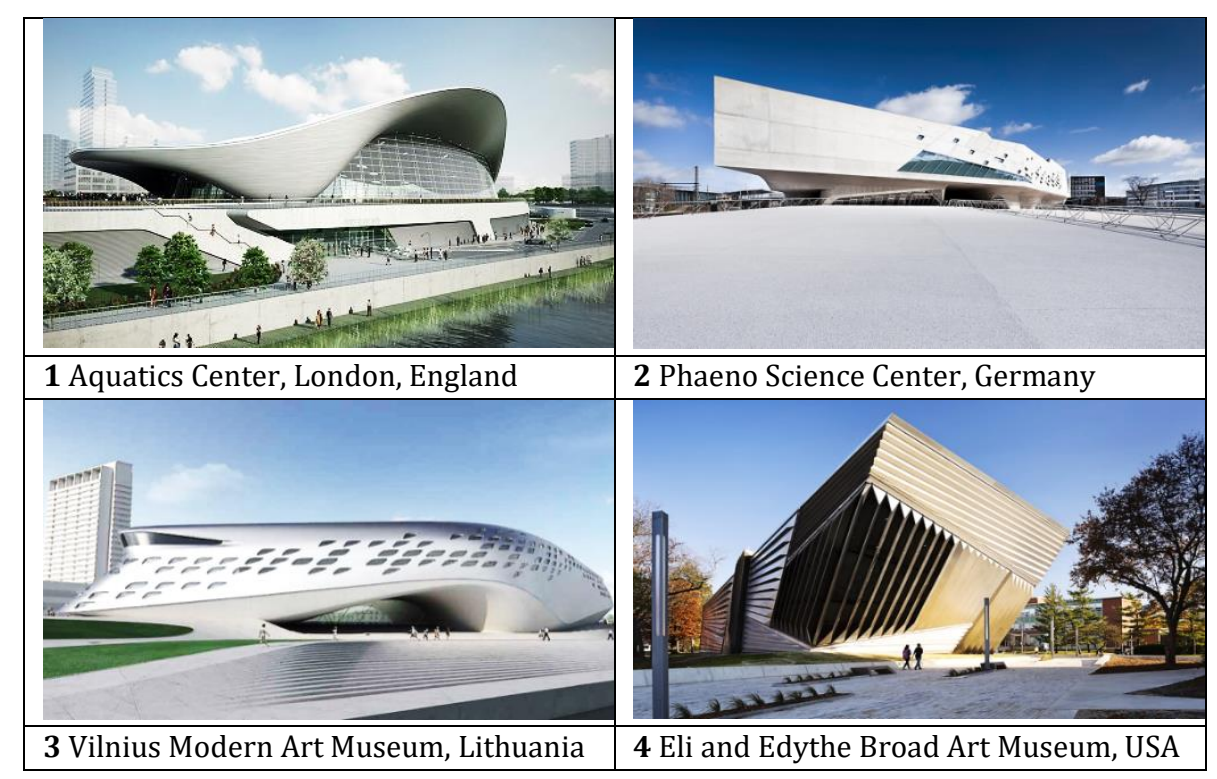


One More Coincide Between Architects And Laypersons On The Aesthetics Of Zaha Hadid's Buildings
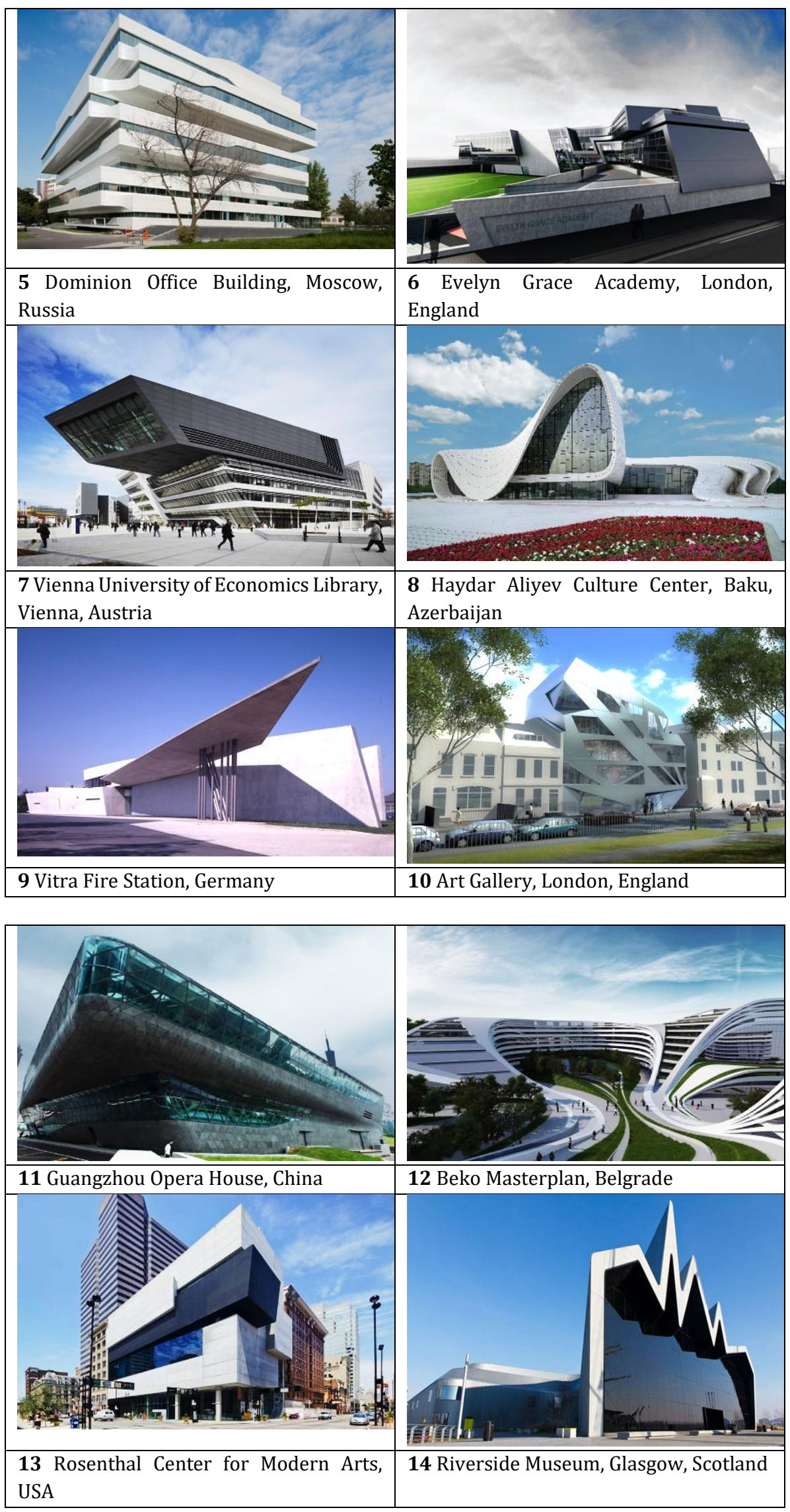


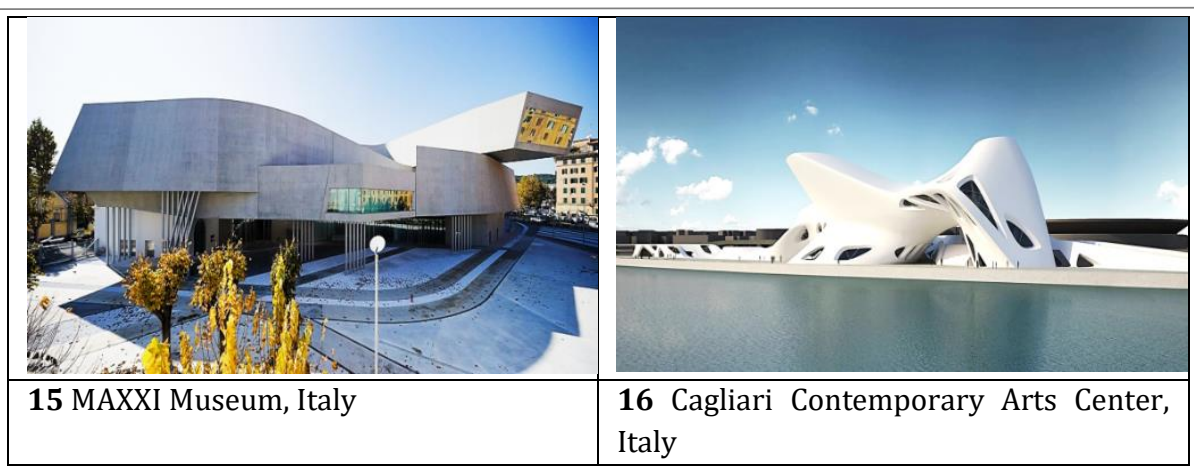

EVALUATION

The SPSS program was used to perform analysis on the participants' ideas and visual aesthetic evaluations regarding Zaha Hadid's buildings. Descriptive statics, correlation analysis and independent $t$ test were performed to conduct the evaluations. Regarding the sensory concept dimension, Cronbach's alpha coefficient was found to be 0.89 , while it was 0.81 for the physical characteristics. The participants' judgements toward Hadid's buildings (whether they liked or not) and their physical and sensory evaluations were determined. According to the analysis results, the participants liked the following images the most, in descending order: Image $8\left(X_{\text {arch }}=6.0 ; X_{\text {lay }}=6.27\right)$, Image $12\left(X_{\text {arch }}=5.9 ; X_{\text {lay }}=6.02\right)$, and Image 1. $\left(X_{\text {arch }}=6.27 ; X_{\text {lay }}=5.80\right)$. They liked the following images the least: Image $13\left(X_{\text {arch }}=3.90 ; X_{\text {lay }}=3.86\right)$, Image $9\left(X_{\text {arch }}=4.0 ; X_{\text {lay }}=4.22\right)$, and Image 2. $\left(X_{\text {arch }}=4.24 ; X_{\text {lay }}=4.24\right)$ (Table1) (Figure 2$)$.

Table 1. Liking rankings of Architects and Laypersons in Zaha Hadid's Buildings

\begin{tabular}{|c|c|c|c|c|c|}
\hline Architect & $\mathrm{N}$ & Mean & Layperson & $\mathrm{N}$ & Mean \\
\hline liking8 & 48 & 6.00 & liking8 & 49 & 6.27 \\
\hline liking12 & 49 & 5.90 & liking12 & 49 & 6.02 \\
\hline liking1 & 49 & 5.67 & liking1 & 49 & 5.80 \\
\hline liking16 & 49 & 5.49 & liking3 & 48 & 5.38 \\
\hline liking3 & 49 & 5.43 & liking14 & 49 & 5.37 \\
\hline liking6 & 49 & 5.35 & liking16 & 49 & 5.29 \\
\hline liking14 & 49 & 5.22 & liking6 & 49 & 5.04 \\
\hline liking6 & 49 & 5.18 & liking11 & 49 & 4.90 \\
\hline liking15 & 49 & 4.98 & liking5 & 49 & 4.80 \\
\hline liking10 & 49 & 4.78 & liking10 & 49 & 4.69 \\
\hline liking4 & 48 & 4.77 & liking4 & 48 & 4.69 \\
\hline liking5 & 49 & 4.73 & liking6 & 49 & 4.67 \\
\hline liking11 & 48 & 4.60 & liking15 & 49 & 4.31 \\
\hline liking2 & 49 & 4.24 & liking13 & 49 & 4.24 \\
\hline liking9 & 49 & 4.00 & liking2 & 49 & 4.22 \\
\hline liking13 & 48 & 3.90 & liking9 & 49 & 3.86 \\
\hline $\begin{array}{l}\text { Valid } \quad \mathrm{N} \\
\text { (listwise) }\end{array}$ & 46 & & $\begin{array}{ll}\text { Valid } & \mathrm{N} \\
\text { (listwise) } & \end{array}$ & 47 & \\
\hline
\end{tabular}

Figure 1 continued Images of Zaha Hadid's Designs Used in the Survey 
Figure 2. The Zaha Hadid Designs Approved the Most (top) or Least (bottom) by Architects and Laypersons
One More Coincide Between Architects And Laypersons On The Aesthetics Of Zaha Hadid's Buildings

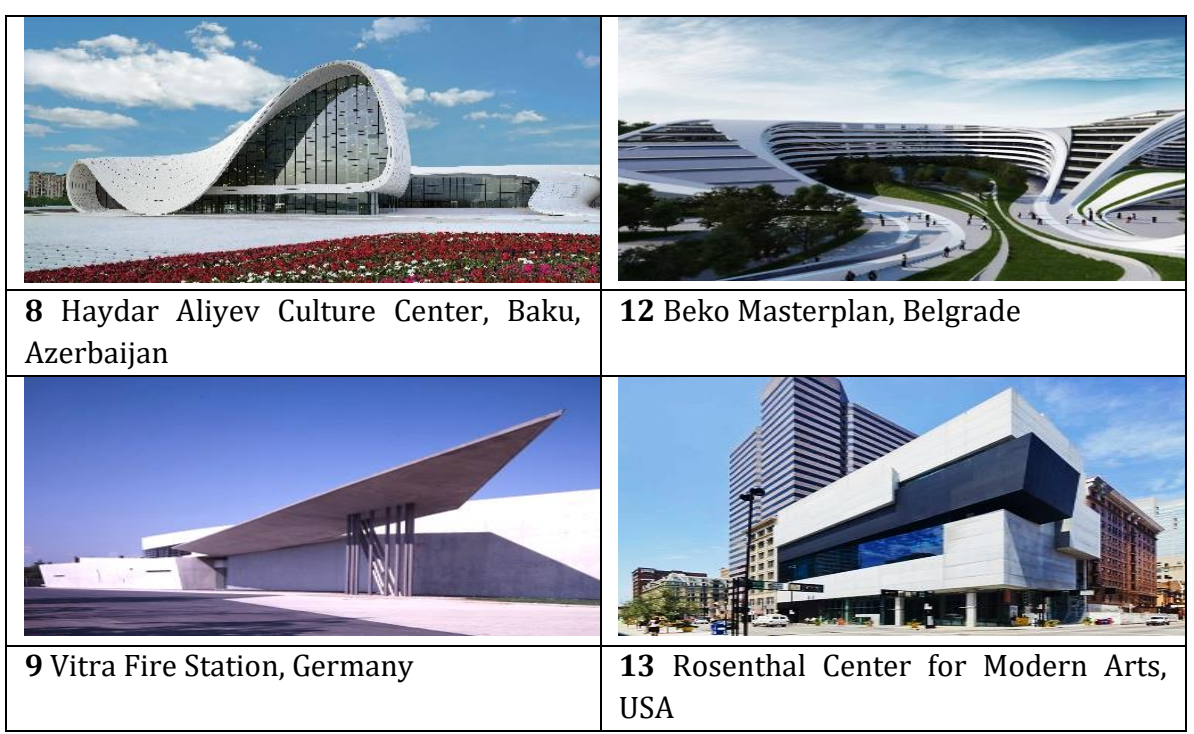

Independent $\mathrm{t}$ test was performed to understand the liking levels of architects and laypersons regarding Hadid's buildings. The mean scores of both groups regarding liking for each image (excluding Image 15) (Table 2) were found to be quite close. The $t$ values regarding the mean scores of both groups indicated that no significant differences were found between the two groups at the 0.05 significance level. Regarding Image 15 , the $t$ value $(t=1.997)$ for the mean scores of both groups indicated a significant difference between them at the 0.05 significance level $(\mathrm{p}=$ 0.049).

Table 2. The Independent T-Test Results Regarding Liking Judgements of Architects and Laypersons

\begin{tabular}{|c|c|c|c|c|c|c|c|}
\hline & & $\mathbf{N}$ & Mean & $\begin{array}{l}\text { Std. } \\
\text { Deviation }\end{array}$ & $\mathbf{F}$ & $\mathbf{t}$ & $\mathbf{p}$ \\
\hline \multirow[t]{2}{*}{ Liking1 } & Architect & 49 & 5.67 & 1.144 & \multirow{2}{*}{0.014} & \multirow{2}{*}{-0.540} & \multirow{2}{*}{0.590} \\
\hline & Layperson & 49 & 5.80 & 1.099 & & & \\
\hline \multirow[t]{2}{*}{ Liking2 } & Architect & 49 & 4.24 & 1.665 & \multirow{2}{*}{1.319} & \multirow{2}{*}{0.056} & \multirow{2}{*}{0.955} \\
\hline & Layperson & 49 & 4.22 & 1.918 & & & \\
\hline \multirow[t]{2}{*}{ Liking3 } & Architect & 49 & 5.43 & 1.258 & \multirow{2}{*}{2.155} & \multirow{2}{*}{0.186} & \multirow{2}{*}{0.853} \\
\hline & Layperson & 48 & 5.38 & 1.566 & & & \\
\hline \multirow[t]{2}{*}{ Liking4 } & Architect & 49 & 4.76 & 1.507 & \multirow{2}{*}{3.375} & \multirow{2}{*}{0.188} & \multirow{2}{*}{0.851} \\
\hline & Layperson & 48 & 4.69 & 2.002 & & & \\
\hline \multirow[t]{2}{*}{ Liking5 } & Architect & 49 & 4.73 & 1.879 & \multirow{2}{*}{1.298} & \multirow{2}{*}{-0.172} & \multirow{2}{*}{0.864} \\
\hline & Layperson & 49 & 4.80 & 1.633 & & & \\
\hline \multirow[t]{2}{*}{ Liking6 } & Architect & 49 & 5.35 & 1.480 & \multirow{2}{*}{4.304} & \multirow{2}{*}{0.861} & \multirow{2}{*}{0.391} \\
\hline & Layperson & 49 & 5.04 & 2.000 & & & \\
\hline \multirow[t]{2}{*}{ Liking7 } & Architect & 49 & 5.18 & 1.467 & \multirow[b]{2}{*}{4.623} & \multirow[b]{2}{*}{1.458} & \multirow[b]{2}{*}{0.148} \\
\hline & Layperson & 49 & 4.67 & 1.962 & & & \\
\hline \multirow[t]{2}{*}{ Liking8 } & Architect & 48 & 6.00 & 1.399 & \multirow{2}{*}{2.005} & \multirow{2}{*}{-1.102} & \multirow{2}{*}{0.273} \\
\hline & Layperson & 49 & 6.27 & 0.930 & & & \\
\hline
\end{tabular}




\begin{tabular}{|c|c|c|c|c|c|c|c|}
\hline \multirow[t]{2}{*}{ Liking9 } & Architect & 49 & 4.00 & 1.646 & \multirow[b]{2}{*}{6.260} & \multirow[b]{2}{*}{0.377} & \multirow[b]{2}{*}{0.707} \\
\hline & Layperson & 49 & 3.86 & 2.082 & & & \\
\hline \multirow[t]{2}{*}{ Liking10 } & Architect & 49 & 4.78 & 1.558 & \multirow[b]{2}{*}{0.062} & \multirow[b]{2}{*}{0.245} & \multirow[b]{2}{*}{0.807} \\
\hline & Layperson & 49 & 4.69 & 1.735 & & & \\
\hline \multirow[t]{2}{*}{ Liking11 } & Architect & 48 & 4.60 & 1.455 & \multirow[b]{2}{*}{2.700} & \multirow[b]{2}{*}{-0.914} & \multirow[b]{2}{*}{0.363} \\
\hline & Layperson & 49 & 4.90 & 1.699 & & & \\
\hline \multirow[t]{2}{*}{ Liking12 } & Architect & 49 & 5.90 & 1.388 & \multirow{2}{*}{0.002} & \multirow{2}{*}{-0.441} & \multirow{2}{*}{0.660} \\
\hline & Layperson & 49 & 6.02 & 1.362 & & & \\
\hline \multirow[t]{2}{*}{ Liking13 } & Architect & 48 & 3.90 & 1.403 & \multirow{2}{*}{4.588} & \multirow{2}{*}{-1.013} & \multirow{2}{*}{0.314} \\
\hline & Layperson & 49 & 4.24 & 1.942 & & & \\
\hline \multirow[t]{2}{*}{ Liking14 } & Architect & 49 & 5.22 & 1.723 & \multirow{2}{*}{0.002} & \multirow{2}{*}{-0.419} & \multirow{2}{*}{0.676} \\
\hline & Layperson & 49 & 5.37 & 1.654 & & & \\
\hline \multirow[t]{2}{*}{ Liking15 } & Architect & 49 & 4.98 & 1.561 & \multirow{2}{*}{0.561} & \multirow{2}{*}{1.997} & \multirow{2}{*}{0.049} \\
\hline & Layperson & 49 & 4.31 & 1.770 & & & \\
\hline \multirow[t]{2}{*}{ Liking16 } & Architect & 49 & 5.49 & 1.757 & \multirow{2}{*}{0.001} & \multirow{2}{*}{0.591} & \multirow{2}{*}{0.556} \\
\hline & Layperson & 49 & 5.29 & 1.658 & & & \\
\hline
\end{tabular}

The levels of warmth the participants felt towards the buildings were determined in the survey. According to the data obtained from analysis results, the buildings reported as the warmest (Image 8 and 12) and coldest (Image 2 and 9) by the architects and laypersons were the same (Table 3).

Table 3. Warmth Rankings of Architects and Laypersons in Zaha Hadid's Designs

\begin{tabular}{|l|l|l|l|l|l|}
\hline Architect & N & Mean & Layperson & N & Mean \\
\hline warm12 & 49 & 5.82 & warm8 & 49 & 5.86 \\
warm8 & 49 & 5.65 & warm12 & 49 & 5.49 \\
warm16 & 49 & 5.14 & warm14 & 49 & 4.86 \\
warm14 & 49 & 4.41 & warm16 & 49 & 4.82 \\
warm1 & 49 & 4.39 & warm1 & 48 & 4.54 \\
warm6 & 49 & 4.37 & warm5 & 49 & 4.33 \\
warm3 & 49 & 4.37 & warm6 & 45 & 4.27 \\
warm5 & 48 & 4.10 & warm3 & 49 & 4.24 \\
warm15 & 49 & 4.06 & warm7 & 47 & 4.21 \\
warm10 & 49 & 4.04 & warm10 & 49 & 3.96 \\
warm7 & 49 & 3.80 & warm13 & 49 & 3.92 \\
warm11 & 49 & 3.73 & warm11 & 49 & 3.80 \\
warm4 & 49 & 3.71 & warm15 & 47 & 3.79 \\
warm13 & 49 & 3.18 & warm4 & 49 & 3.57 \\
warm9 & 49 & 3.02 & warm2 & 48 & 3.10 \\
warm2 & 49 & 2.88 & warm9 & 49 & 2.86 \\
Valid & $\mathrm{N}$ & 48 & & Valid & $\mathrm{N}$ \\
(listwise) & & & (listwise) & 43 & \\
\hline
\end{tabular}


One More Coincide Between Architects And Laypersons On The Aesthetics Of Zaha Hadid's Buildings

Independent $t$ test was performed to understand the sensorial concepts of the architects and laypersons regarding Zaha Hadid's buildings. In terms of the complexity, the mean score of the architects was found to be $68.41+-10.427$, while the mean score of the laypersons was $74.00+-$ 12.116 (Table 4$)$. The $t$ value $(t=0.186)$ of the mean scores for both groups indicated a significant difference between them at the 0.05 significance level $(\mathrm{p}=0.020)$. A significant difference was found between the scores of the architects and laypersons in complexity dimension. Similarly, the $t$ values ( $\mathrm{t}_{\text {familiar }}=0.188$; $\mathrm{t}_{\text {ornate }}=0.301$ ) calculated to test the significance of the difference between the mean scores of the architects and laypersons in the familiarity and ornate dimension indicated that the difference between the two groups ( $\left.p_{\text {familiar }}=0.011 ; p_{\text {ornate }}=0.012\right)$ was significant in these dimensions at the 0.05 significance level.

However, the $t$ values calculated to test the significance of the difference between the two groups in the liking, pleasant, attractive, meaningful and warm dimensions $\left(\mathrm{t}_{\text {liking }}=0.165 ; \mathrm{t}_{\text {pleasant }}=0.834 ; \mathrm{t}_{\text {attractive }}=0.575 ; \mathrm{t}_{\text {meaningful }}=\right.$ $0.575 ; \mathrm{t}_{\mathrm{warm}}=0.372$ ) indicated no significant difference between them regarding these dimensions $\left(p_{\text {liking }}=0.568 ; p_{\text {pleasant }}=0.998 ; p_{\text {attractive }}=\right.$ $0.634 ; p_{\text {meaningful }}=0.418 ; p_{\text {warm }}=0.950$ ) at the 0.05 significance level. In other words, no significant difference was found between the architects and laypersons regarding the liking, pleasant, attractive, meaningful and warm dimensions.

Table 4. Results of Independent t test for Sensorial Concepts of Architects and Laypersons in Zaha Hadid's Buildings

\begin{tabular}{|c|c|c|c|c|c|c|}
\hline & Section & $\mathrm{N}$ & Mean & $\begin{array}{l}\text { Std. } \\
\text { Deviation }\end{array}$ & $\mathrm{F}$ & $\mathrm{p}$ \\
\hline \multirow[t]{2}{*}{ Liking } & Architect & 47 & 81.00 & 12.003 & & \\
\hline & Layperson & 47 & 79.38 & 15.150 & 1.9560 .165 & 0.568 \\
\hline \multirow[t]{2}{*}{ Pleasant } & Architect & 47 & 80.29 & 13.639 & & \\
\hline & Layperson & 49 & 80.30 & 14.208 & 0.0440 .834 & 0.998 \\
\hline \multirow[t]{2}{*}{ Complex } & Architect & 46 & 68.41 & 10.427 & & \\
\hline & Layperson & 46 & 74.00 & 12.116 & 2.1550 .186 & 0.020 \\
\hline \multirow[t]{2}{*}{ Familiar } & Architect & 49 & 62.81 & 14.932 & & \\
\hline & Layperson & 46 & 54.67 & 15.490 & 3.3750 .188 & 0.011 \\
\hline \multirow[t]{2}{*}{ Attractive } & Architect & 47 & 74.42 & 12.051 & & \\
\hline & Layperson & 48 & 75.68 & 13.597 & 0.3170 .575 & 0.634 \\
\hline \multirow[t]{2}{*}{ Meaningful } & Architect & 46 & 71.08 & 14.206 & & \\
\hline & Layperson & 47 & 68.61 & 15.045 & 0.3170 .575 & 0.418 \\
\hline \multirow[t]{2}{*}{ Warm } & Architect & 48 & 66.97 & 10.982 & & \\
\hline & Layperson & 43 & 66.81 & 13.903 & 0.8060 .372 & 0.950 \\
\hline \multirow[t]{2}{*}{ Ornate } & Architect & 46 & 63.78 & 14.167 & & \\
\hline & Layperson & 46 & 71.10 & 13.313 & 1.0830 .301 & 0.012 \\
\hline
\end{tabular}

Correlation values were examined to evaluate the relationships between the sensorial (liking, pleasant/unpleasant, complex/simple, attractive/unattractive, meaningful/meaningless, ornate/pure, 
warm/cold) and physical (regular/irregular, curvilinear, fullbulky/empty-massless, rhythmic/arrhythmic, soft/hard, symmetric/asymmetric) characteristics. The $\mathrm{r}$ values calculated for that purpose indicated a significant relationship between sensory concepts and physical characteristics at the 0.05 significance level. Regarding symmetric, no significant relationship was found between any of the sensory concepts. In addition, an inverse relationship was present between complexity and regularity, but no significant relationship with fullness was found. Moreover, no significant relationship was present between familiarity and curvilinearity, and ornate, warm and regularity. Analysis results further indicated that almost all of the sensory concepts were most related to rhythmic and soft concepts. Overall, it was revealed that the rhythmic and soft (organic) lines of a building were the most significant elements for facades and buildings in the aesthetic evaluation (Table5).

Table 5. The Correlation Values Between the Sensorial and Physical Characteristics of Zaha Hadid's Buildings

\begin{tabular}{|c|c|c|c|c|c|c|c|c|}
\hline & & & REG. & CURV. & FULL & RHYT. & SOFT & SYM. \\
\hline & APPROVAL & $\begin{array}{l}\text { Pearson } \\
\text { Correlation } \\
\text { Sig. (2-tailed) } \\
\mathrm{N}\end{array}$ & $\begin{array}{l}0.578^{*} \\
0.019 \\
16\end{array}$ & $\begin{array}{l}0.844^{* *} \\
0.000 \\
16\end{array}$ & $\begin{array}{l}0.839 * * * \\
0.000 \\
16\end{array}$ & $\begin{array}{l}0.943^{* *} \\
0.000 \\
16\end{array}$ & $\begin{array}{l}0.872^{* *} \\
0.000 \\
16\end{array}$ & $\begin{array}{l}0.337 \\
0.202 \\
16\end{array}$ \\
\hline & PLEASANT & $\begin{array}{l}\text { Pearson } \\
\text { Correlation } \\
\text { Sig. (2-tailed) } \\
\mathrm{N}\end{array}$ & $\begin{array}{l}0.525^{*} \\
0.037 \\
16\end{array}$ & $\begin{array}{l}0.825^{* *} \\
0.000 \\
16\end{array}$ & $\begin{array}{l}0.798^{* *} \\
0.000 \\
16\end{array}$ & $\begin{array}{l}0.950^{* *} \\
0.000 \\
16\end{array}$ & $\begin{array}{l}0.848^{* *} \\
0.000 \\
16\end{array}$ & $\begin{array}{l}0.341 \\
0.197 \\
16\end{array}$ \\
\hline & COMPLEX & $\begin{array}{l}\text { Pearson } \\
\text { Correlation } \\
\text { Sig. (2-tailed) } \\
\mathrm{N}\end{array}$ & $\begin{array}{l}-0.119 \\
0.660 \\
16\end{array}$ & $\begin{array}{l}0.649^{* *} \\
0.006 \\
16\end{array}$ & $\begin{array}{l}0.460^{*} \\
0.073 \\
16\end{array}$ & $\begin{array}{l}0.624^{* *} \\
0.010 \\
16\end{array}$ & $\begin{array}{l}0.558^{*} \\
0.025 \\
16\end{array}$ & $\begin{array}{l}0.193 \\
0.474 \\
16\end{array}$ \\
\hline 出 & FAMILIAR & $\begin{array}{l}\text { Pearson } \\
\text { Correlation } \\
\text { Sig. (2-tailed) } \\
\mathrm{N}\end{array}$ & $\begin{array}{l}0.701^{* *} \\
0.002 \\
16\end{array}$ & $\begin{array}{l}0.341 \\
0.197 \\
16\end{array}$ & $\begin{array}{l}0.533^{*} \\
0.034 \\
16\end{array}$ & $\begin{array}{l}0.580^{*} \\
0.019 \\
16\end{array}$ & $\begin{array}{l}0.616^{*} \\
0.011 \\
16\end{array}$ & $\begin{array}{l}0.489 \\
0.054 \\
16\end{array}$ \\
\hline 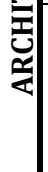 & ATTRACTIVE & $\begin{array}{l}\text { Pearson } \\
\text { Correlation } \\
\text { Sig. (2-tailed) } \\
\mathrm{N}\end{array}$ & $\begin{array}{l}0.564^{*} \\
0.023 \\
16\end{array}$ & $\begin{array}{l}0.844^{* *} \\
0.000 \\
16\end{array}$ & $\begin{array}{l}0.824^{* *} \\
0.000 \\
16\end{array}$ & $\begin{array}{l}0.956^{* *} \\
0.000 \\
16\end{array}$ & $\begin{array}{l}0.884^{* *} \\
0.000 \\
16\end{array}$ & $\begin{array}{l}0.377 \\
0.149 \\
16\end{array}$ \\
\hline & MEANINGFUL & $\begin{array}{l}\text { Pearson } \\
\text { Correlation } \\
\text { Sig. (2-tailed) } \\
\mathrm{N} \\
\end{array}$ & $\begin{array}{l}0.597^{*} \\
0.015 \\
16\end{array}$ & $\begin{array}{l}0.804^{* *} \\
0.000 \\
16\end{array}$ & $\begin{array}{l}0.784^{* *} \\
0.000 \\
16\end{array}$ & $\begin{array}{l}0.913^{* *} \\
0.000 \\
16\end{array}$ & $\begin{array}{l}0.846^{* *} \\
0.000 \\
16\end{array}$ & $\begin{array}{l}0.329 \\
0.214 \\
16\end{array}$ \\
\hline & ORNATE & $\begin{array}{l}\text { Pearson } \\
\text { Correlation } \\
\text { Sig. (2-tailed) } \\
\mathrm{N}\end{array}$ & $\begin{array}{l}0.177 \\
0.512 \\
16\end{array}$ & $\begin{array}{l}0.820^{* *} \\
0.000 \\
16\end{array}$ & $\begin{array}{l}0.710^{* *} \\
0.002 \\
16\end{array}$ & $\begin{array}{l}0.802^{* *} \\
0.000 \\
16\end{array}$ & $\begin{array}{l}0.815^{* *} \\
0.000 \\
16\end{array}$ & $\begin{array}{l}0.278 \\
0.296 \\
16\end{array}$ \\
\hline & WARM & $\begin{array}{l}\text { Pearson } \\
\text { Correlation } \\
\text { Sig. (2-tailed) } \\
\mathrm{N}\end{array}$ & $\begin{array}{l}0.495 \\
0.051 \\
16\end{array}$ & $\begin{array}{l}0.809^{* *} \\
0.000 \\
16\end{array}$ & $\begin{array}{l}0.716^{* *} \\
0.002 \\
16\end{array}$ & $\begin{array}{l}0.922^{* *} \\
0.000 \\
16\end{array}$ & $\begin{array}{l}0.911^{* *} \\
0.000 \\
16\end{array}$ & $\begin{array}{l}0.430 \\
0.097 \\
16\end{array}$ \\
\hline
\end{tabular}


One More Coincide Between Architects And Laypersons On The Aesthetics Of Zaha Hadid's Buildings

\begin{tabular}{|c|c|c|c|c|c|c|c|}
\hline APPROVAL & $\begin{array}{l}\text { Pearson } \\
\text { Correlation } \\
\text { Sig. (2-tailed) } \\
\mathrm{N}\end{array}$ & $\begin{array}{l}0.566^{*} \\
0.022 \\
16\end{array}$ & $\begin{array}{l}0.882^{* *} \\
0.000 \\
16\end{array}$ & $\begin{array}{l}0.820^{* *} \\
0.000 \\
16\end{array}$ & $\begin{array}{l}0.945^{* *} \\
0.000 \\
16\end{array}$ & $\begin{array}{l}0.913^{* *} \\
0.000 \\
16\end{array}$ & $\begin{array}{l}0.377 \\
0.150 \\
16\end{array}$ \\
\hline PLEASANT & $\begin{array}{l}\text { Pearson } \\
\text { Correlation } \\
\text { Sig. (2-tailed) } \\
\text { N }\end{array}$ & $\begin{array}{l}0.675^{* *} \\
0.004 \\
16\end{array}$ & $\begin{array}{l}0.804^{* *} \\
0.000 \\
16\end{array}$ & $\begin{array}{l}0.830^{* *} \\
0.000 \\
16\end{array}$ & $\begin{array}{l}0.911^{* *} \\
0.000 \\
16\end{array}$ & $\begin{array}{l}0.878^{* *} \\
0.000 \\
16\end{array}$ & $\begin{array}{l}0.478 \\
0.061 \\
16\end{array}$ \\
\hline COMPLEX & $\begin{array}{l}\text { Pearson } \\
\text { Correlation } \\
\text { Sig. (2-tailed) } \\
\mathrm{N}\end{array}$ & $\begin{array}{l}0.045 \\
0.868 \\
16\end{array}$ & $\begin{array}{l}0.663^{* *} \\
0.005 \\
16\end{array}$ & $\begin{array}{l}0.593^{*} \\
0.015 \\
16\end{array}$ & $\begin{array}{l}0.735^{* *} \\
0.001 \\
16\end{array}$ & $\begin{array}{l}0.573^{*} \\
0.020 \\
16\end{array}$ & $\begin{array}{l}0.269 \\
0.313 \\
16\end{array}$ \\
\hline FAMILIAR & $\begin{array}{l}\text { Pearson } \\
\text { Correlation } \\
\text { Sig. (2-tailed) } \\
\mathrm{N}\end{array}$ & $\begin{array}{l}0.530^{*} \\
0.035 \\
16\end{array}$ & $\begin{array}{l}-0.073 \\
0.788 \\
16\end{array}$ & $\begin{array}{l}0.201 \\
0.456 \\
16\end{array}$ & $\begin{array}{l}0.254 \\
0.342 \\
16\end{array}$ & $\begin{array}{l}0.259 \\
0.332 \\
16\end{array}$ & $\begin{array}{l}0.591^{*} \\
0.016 \\
16\end{array}$ \\
\hline ATTRACTIVE & $\begin{array}{l}\text { Pearson } \\
\text { Correlation } \\
\text { Sig. (2-tailed) } \\
\mathrm{N}\end{array}$ & $\begin{array}{l}0.478 \\
0.061 \\
16 \\
\end{array}$ & $\begin{array}{l}0.869^{* *} \\
0.000 \\
16 \\
\end{array}$ & $\begin{array}{l}0.820^{* *} \\
0.000 \\
16 \\
\end{array}$ & $\begin{array}{l}0.937^{* *} \\
0.000 \\
16\end{array}$ & $\begin{array}{l}0.918^{* *} \\
0.000 \\
16\end{array}$ & $\begin{array}{l}0.476 \\
0.062 \\
16\end{array}$ \\
\hline MEANINGFUL & $\begin{array}{l}\text { Pearson } \\
\text { Correlation } \\
\text { Sig. (2-tailed) } \\
\mathrm{N}\end{array}$ & $\begin{array}{l}0.673^{* *} \\
0.004 \\
16\end{array}$ & $\begin{array}{l}0.744^{* *} \\
0.001 \\
16\end{array}$ & $\begin{array}{l}0.880^{* *} \\
0.000 \\
16\end{array}$ & $\begin{array}{l}0.948^{* *} \\
0.000 \\
16\end{array}$ & $\begin{array}{l}0.873^{* *} \\
0.000 \\
16\end{array}$ & $\begin{array}{l}0.568^{*} \\
0.022 \\
16\end{array}$ \\
\hline ORNATE & $\begin{array}{l}\text { Pearson } \\
\text { Correlation } \\
\text { Sig. (2-tailed) } \\
\mathrm{N} \\
\end{array}$ & $\begin{array}{l}0.333 \\
0.208 \\
16 \\
\end{array}$ & $\begin{array}{l}0.801^{* *} \\
0.000 \\
16 \\
\end{array}$ & $\begin{array}{l}0.718^{* *} \\
0.002 \\
16 \\
\end{array}$ & $\begin{array}{l}0.880^{* *} \\
0.000 \\
16 \\
\end{array}$ & $\begin{array}{l}0.830^{* *} \\
0.000 \\
16 \\
\end{array}$ & $\begin{array}{l}0.504^{*} \\
0.047 \\
16 \\
\end{array}$ \\
\hline WARM & $\begin{array}{l}\text { Pearson } \\
\text { Correlation } \\
\text { Sig. (2-tailed) } \\
\mathrm{N}\end{array}$ & $\begin{array}{l}0.544^{*} \\
0.029 \\
16\end{array}$ & $\begin{array}{l}0.739^{* *} \\
0.001 \\
16\end{array}$ & $\begin{array}{l}0.710^{* *} \\
0.002 \\
16\end{array}$ & $\begin{array}{l}0.899^{* *} \\
0.000 \\
16\end{array}$ & $\begin{array}{l}0.862^{* *} \\
0.000 \\
16\end{array}$ & $\begin{array}{l}0.493 \\
0.053 \\
16\end{array}$ \\
\hline
\end{tabular}

To summarize the assessments of all the analysis made, in the aesthetics evaluations carried out on Zaha Hadid designs;

- The first three images that architects and laypersons like and dislike were the same.

- With the exception of the MAXXI Museum, there was no significant difference in liking dimension between architects and laypersons.

- Two images that architects and laypersons found the warmest and the coldest were the same (Table 4). The architects and laypersons arrived at a consensus on the images of Haydar Aliyev Cultural Center and Beko Building as the warmest and on the images of Phaeno Science Center and Vitra Fire Station as the coldest.

- There was a significant difference between architects and laypersons in terms of familiarity, ornateness and complexity.

- There was no significant difference between architects and laypersons in terms of liking, pleasant, attractive, meaningful and warm.

- When the relation between the sensory and physical characteristics of the buildings are examined, it is seen that almost all sensory concepts are associated with rhythmic and soft concepts at the highest level. In other 
words, it has been determined that the rhythmic and soft (organic) lines of a building were the most substantial facts for facades and masses in the general aesthetic evaluation.

\section{DISCUSSION AND CONCLUSION}

The concept of dynamism, which is intensively used in modern architecture discourse, is one of the most basic elements of the "new architecture" language based on scientific information. Dynamism is used as one of the main concepts defining the basic characteristics of the modern world with regard to the ideas of complexity, chaos and heterogeneity and social, cultural and economic aspects. Studies examining the dynamism of the new world in architecture should be conducted. Patrick Schumacher of Zaha Hadid Architects stated that Hadid made efforts to inject a new dynamism into architecture with the recent designs of multi-story buildings, and according to him, these efforts aimed to form an architecture language with fluent and applicable characteristics that would solve the increasing social and urban complexity. Schumacher said that the organic and inorganic natural systems were the inspiration of this new architectural language. Investigations of the abstraction in architecture indicate that both geometric and non-geometric abstraction types were applied in Zaha Hadid's designs. In this sense, when looking at today's designs, it is seen that Zaha Hadid's designs stand out from the others with their distinctive features.

The question of the meaning an architectural building has in terms of its location is significant for creating environments that can be regarded as satisfactory by all people of today. This is the case, because the conceptual satisfaction approaches toward building and the perception and interpretation styles that people have vary according to the current identity and language of all buildings. This study evaluated whether there is a common language in evaluating the perception and satisfaction of subjects with different backgrounds (educational statuses) and analyzed the impacts of this language in forming a universal language by examining Zaha Hadid's buildings/designs.

Independent $t$ test was performed to understand the sensory concept levels of the architects and laypersons regarding Zaha Hadid's buildings. According to the analysis results, a significant difference was found between the architect and layperson groups in the "complexity", "familiarity" and "ornate" dimensions, in parallel with the studies in the literature (Venturi, 1966; Purcell et al., 1998; Jeffrey et al., 1999; Imamoglu, 2000; Akalin et al., 2009; Akalin et al., 2010). However, the $t$ values calculated to test the significance of the difference between the two groups regarding the "liking", "pleasant", "attractive", "meaningful", and "warm" dimensions indicated there to be no significant difference. Two buildings (Image 8 and 12) found to be the warmest and most pleasant by the architects and laypersons were the same. Both groups 
liked the buildings they regarded as warm. The buildings (excluding Image 15) liked and disliked by both groups were found to match. Few studies find similarities between architects and laypersons. While Kunawong (1986) used LISREL (Linear Structural Relationships) analysis in his study, Küller (1973) used the "agent analysis". The results obtained did not go beyond some adjective similarities. This study supports those studies also showing there to be no differences between architect-layperson groups (Kunawong, 1986; Küller, 1973; Özbudak Akça et al., 2015). These results indicate that the individual style in Hadid's designs play a key role in aesthetic decisions, and that individual style may include efforts to achieve a common language. Contributing to studies on environmental aesthetics on how subjects with different backgrounds of this finding perceive their physical environment in terms of semantics, in addition to studies that try to reveal the ground of the relation of visual perception with parametric design in buildings built with the parametric design approach (Basu and Ghosh, 2018) would also provide a different perspective. Thus, the design process of the study is expected to guide the future framework that makes the world a better place to live with a more efficient, effective, optimum and rational intellection.

Correlation values were examined to evaluate the relationships between the sensory (liking, pleasant/unpleasant, complex/simple, attractive/unattractive, meaningful/meaningless, ornate/pure, warm/cold) and physical (regular/irregular, curvilinear, fullbulky/empty-massless, rhythmic/arrhythmic, soft/hard, symmetric/asymmetric) characteristics. According to analysis results, no significant relationship was found between any of the sensory concepts in terms of being symmetric. Almost all of the sensory concepts were most related to rhythmic and soft concepts. The results further showed that the rhythmic and soft (organic) lines of a building were the most meaningful elements for facades and masses in the aesthetic evaluation. Such data can be used to constitute criteria for the production of highquality outdoors or indoors. This study is important due to providing a framework for establishing building quality criteria.

One of the most significant results of the concretization performed to understand which physical characteristics were involved in perceiving facades is that the subject can be learned and taught through the acquired state of objectivity. This paves the way for education and training, which are the main paths to personal development. Architect candidates who know these qualities and keep them in mind will be able to create high quality architectonic environments that are visually enjoyed by many once the architecture and society are improved. Designers should be aware of the psychological states, personalities, perceptions, cognitions and behaviors of the users of spaces and environments, and students should be taught about this awareness as part of their educational curriculum. 
Architectural meaning should be considered as whole together with usage and style. In its period of emergence and inception as a criticism object in designing, architecture has been one of the critical factors affecting the spaces as the actual products, the spatial users, and the locations of the spaces. Contemporary architecture exhibits a variety of styles that can be achieved through new materials, rapid technological development and static possibilities. Buildings constructed without observing the environmental compatibility have led to reactions against contemporary architecture. There is growing discontent with the fact that technology has become a goal, to the neglect of symbolic and regional values. The works of Zaha Hadid, who changed this concept, pushing it beyond its boundaries, indicate that they belong to no specific time (timelessness), have fluent forms, use free forms, reflect costly designs requiring advanced technology, parametric designs and utilize the virtual environment in designs. With these works, Zaha Hadid has formed her own "individual style". As a result, it is only natural that changes made to a country's architecture will be under the influence of new architectural theories based on the ever-changing technology. If the architecture of a society can be connected with certain features from time to time, despite the external factors, then the architecture can become original to that society. For example, if the chain is not broken, a common preserved aspect remains intact, despite the differences in the rings. It is possible to see this in Hadid's structures. This study is significant insofar as it is among the rare studies that found there to be no differences between architects and laypersons, revealing instead that they had primarily similar aesthetic evaluations. The findings from this study can serve as a guide to achieving common (liking-related) evaluations through a building's physical characteristics and to forming the buildings to be designed in the future, and furthermore, the findings will contribute to future environmental aesthetic studies in terms of how subjects with different background perceive environmental conditions.

\section{CONFLICT OF INTEREST}

No conflict of interest was declared by the authors.

\section{FINANCIAL DISCLOSURE}

The authors declared that this study has received no financial support.

\section{ETHICS COMMITTEE APPROVAL}

Ethics committee approval was not required for this article.

\section{LEGAL PUBLIC/PRIVATE PERMISSIONS}

In this research, the necessary permissions were obtained from the relevant participants (individuals, institutions and organizations) during the survey, in-depth interview, focus group interview, observation or experiment. 
One More Coincide Between Architects And Laypersons On The Aesthetics Of Zaha Hadid's Buildings

\section{REFERENCES}

Abercrombie, S. (1984). Architecture as art: an aesthetic analysis. Newyork: Van Nostrand Reinhold Company.

Ackerman, J.S. (1963). "Style", Art and Archaelogy. Prentice, Englewood Cliffs, NJ, 174-186.

Amer, M., Attia, S. (2019). Identification of sustainable criteria for decision-making on roof stacking construction method. Sustainable Cities and Society, 47 (February), 101456.

https://doi.org/10.1016/j.scs.2019.101456.

Aydınl, S. (1993). Aesthetic values in architecture. First Edition. Istanbul: İ.T.Ü. Faculty of Architecture Printing Studio.

Basu, T, Ghosh, M. (2018). Visual perception of space and parametric design: A brief discussion, GSTF Journal of Engineering Technology, pp 111. DOI: $10.5176 / 2251-3701 \_4.2 .185$,

Benedikt, M.L. (1979). To take hold of space: Isovists and isovist fields. Environment and Planning B: Planning and Design. 6(1):47-65.

Brown, G., Gifford, R. (2001). Architects predict lay evaluations of large contemporary buildings: whose conceptual properties?. Journal of Environmental Psychology, (21) 93-9.

Canter, D. (1969). An intergroup comparison of connotative dimensions in architecture. Environment and Behavior, (1) 27-28.

Chan, C. S. (2000). Can style be measured?. Design Studies, 21(3), 277291.

Devlin, K., Nasar, J.L. (1989). The beauty and the beast: some preliminary comparisions of 'high' versus 'popular' residential architecture and public versus architect judgements of same. Journal of Environmental Psychology, (9), 333-44.

Devlin, K. (1990). An examination of architectural interpretation: architects versus nonarchitects. Journal of Architectural and Planning Research (7), 235-43.

Erdoğan, E. (2010). Stil ve Tasarım Eğitimi. İstanbul: Yapı Dergisi, 342, 6265.

Erdogan, E., Akalin, A., Yıldırım, K., Erdoğan, H.A. (2010a). Aesthetic differences between freshmen and pre-architects. Gazi University Journal of Science, 23 (4), 5011-50.

Erdogan E, Akalin A, Yildirim K, Erdogan H. A. (2010b). Students' evaluations of different architectural styles. Procedia Social and Behavioral Sciences, WCPCG-2010, 5, 875-881.

Erzen, J.N. (2006). Çevre Estetiği. Ankara: Odtü Geliștirme Vakfı publishing, İletişim publication.

Fawcett, W., Ellingham, T., Platt, S. (2008). Reconciling the Architectural Preferences of Architects and the Public. Environment and Behavior, Vol.40, No.5, 599-618.

Greene, T.M. (1940). The Arts and the Art of Critisism. Princeton: Princeton University Press, 5-12. 
Groat, L. (1982). Meaning in Post-Modern architecture: An examination using the multiple sorting task. Journal of Environmental Psychology, (2), 3- 22.

Gifford, R., Hine, D., Clemm, W., Shaw, K. (2000). Decoding Modern Architecture: A Lens Approach for Understanding the Aesthetics Differences of Architects and Laypersons. Environment and Behaviour, 32 (2), 163-87.

Gifford, R., Hine, D., Clemm, W., Shaw, K. (2002). Why Architects and Laypersons Judge Building Differently: Cognitive Properties and Physical Bases. Journal of Architectural and Planning Research, 19 (2), 131-48.

Hershberger, R. C. (1969). A study of meaning in architecture, Proceedings of the Environmental Design Research Association, ed. H. Sanoff, S. Cohn, Raleigh, ABD:NC: North Carolina State University.

Hersberger, G. R. (1988). A Study of Meaning And Architecture, Environmental Aesthetics Theory Research and Applications, Cambridge University Press, New York, 175-94.

Hershberger, R. G., Cass, R. C. (1988). Predicting user responses to buildings, in J. L. Nasar, (Eds.), Environmental aesthetics: Theory, research, and applications, New York: Cambridge University Press., 195-211.

Hubbard, P. (1996). Conflicting Interpretations of Architecture: An Empirical Investigation, Journal of Environmental Psychology, (16), 7592.

İmamoğlu, V. (1979). Assessment of living rooms by households and architects, Proceedings of the 4th Conference of the International Association for the People and Their Physical Environment, Louvain le Neuve, Belgium, 65-85.

İmamoğlu, Ç. (2000). Complexity, liking and familiarity: architecture and non-architecture Turkish students' assessments of traditional and modern house facades. Journal of Environmental Psychology, 20, 5-16.

Jenks, C. (1977). The Language of Post-modern architecture. New York: Rizzoli.

Jencks, C. (1980). The architectural sign, sign-symbols and architecture. pp. 71-118, Eds. Broadbent, G.,Bunt, R.,Jencks, C., New York: John Wileyand Sons Ltd.

Kaplan, R. (1974). Predictors of environmental preference: Designers and 'clients', in F.E. Wolfgang, (Eds.), Proceedings of the 4th Conference of the Environmental Design and Research Association. Stroudsburg: Dowden, Hutchinson and Ross, 265-274.

Krampen, M., Öztürk, K., Saltik, H., Özek, V. (1978). Eski ve yeni görünüşlerin öznel izlenimleri ve nesnel ölçümleri, KTU Mimarlık Bölümü Mimarlık Bülteni.

Kunawong, C. (1986). The Study of Responses to Architectural Exteriors by Architectural and Non-Architectural Students, Unpublished Phd. Thesis, Ohio State University, ABD.

Kuller, R. (1973). Beyond Semantic Measurement, Architectural Psychology, ed. R. Küller. Lund Procedings of 2. International 
One More Coincide Between Architects And Laypersons On The Aesthetics Of Zaha Hadid's Buildings

Architectural Psychology Conference, Stroudsburg, Pa., Dowden, Hutchinson \& Ross, 181-97.

Larue, J. (1970). Guidelines for Style Analysis. New York: W.W. Norton, ix.

Lang, J. (1987). Fundamental Processes of Human Behaviour Creating architectural Theory, The Role of theBehavioural Science Environmantal Design, Van Nostrand Reinhold.

Maalqe, E. (1973). The Aesthetic Joyand Repetition of the Ever Unpredictable, ed. R.

Küller, Dowden, Hutchinson and Ross. Inc., Stroudsburg, Penn.

Nasar, J.L., Kang, J. (1989). A post-jury evaluation, Environment and Behavior. (21), 464- 84.

Nasar, J.L. (1989a). Perception, cognition and evaluation of urban places. In I. Altman, \& E.H. Zube (Eds), Public Places and Spaces: Human Behaviour and Environment, vol.10, 31-56.

Nasar, J.L. (1989b). Symbolic meanings of house styles. Environment and Behaviour, 21, 235-257.

Nasar, J.L., Purcell, A. T. (1990). Beauty and the beast extended: Knowledge structure and evaluation of houses by Australian architect and non architect students. Culture, Space, History: Proceedings of the 11th Conference of the International Association for the People and Their Physical Environment 1, ed. H.Pamir, V. İmamoğlu, N. Teymur, 1, ODTÜ, Ankara, 169-71.

Nasar, J.L., (2008). Assessing Perceptions of Environments for Active Living, American Journal of Preventive Medicine, 34 (4): 357-363.

Özbudak Akça, B., Erdoğan, E., Akalın, A., (2015). A Study of Architects' Understanding of Laypersons' Language; Similarity of Architect and Layperson. METU Journal of the Faculty of Architecture, 32(2):171-189.

Purcell, A.T. (1995). Experiencing American and Australian high and popular-style houses. Environment and Behavior, (27), 771- 801.

Purcell, A.T., Peron, E., Sanchez, C. (1998). Subcultural and cross-cultural effects on the experience of detached houses: An examination of two models of affective experience of the environment. Environment and Behavior, (30) 348-77.

Rapoport, A. (1977). Human Aspects of Urban Form. Oxford: Pergamon.

Rapoport, A. (1980). Human Aspects of Urban Form, Towards a ManEnvironment Approach to Urban Form and Design. Pergamon Press, Oxford, New York, Toronto, Sydney, Paris, Frankfurt.

Sadalla, E.K., Sheets, V.L. (1993). Symbolism in building materials: selfpresentational and cognitive components. Environment and Behavior, vol.25 no.2, 155-180.

Sánchez-Pantoja, N., Vidal, R., \& Pastor, M. C. (2018). Aesthetic perception of photovoltaic integration within new proposals for ecological architecture. Sustainable Cities and Society, 39(February), 203-214. https://doi.org/10.1016/j.scs.2018.02.027. 
Sandstrom, S. (1973). Socio- cultural theory of aesthetic visual estimation and use. Architectural Psychology, ed. R. Küller, Dowden, Hutchinson and Ross. Inc., Stroudsburg, Penn.

Sanoff, H. (1974). Measuring Attributes of the Visual Environment. Designing For Human Behavior Architecture and Behavioral Sciences, ed. J. Lang, Dowden Hutchinson and Ross. Inc., Stroudsburg, Penn.

Schapiro, M. (1961). Style, In: M. P. Philipson (Ed), Aesthetics Today. World Publishing, Cleveland, OH, 81-113.

Schulz, N. C. (1965). Intentions in Architecture. London: M.I.T., Press, Cambridge Studio Vista.

Smith, C.S. (1981). A search for structure: selected essays on science, art and history. London: MIT Press, Cambridge, MA, 359.

Stanislav, A., \& Chin, J. T. (2019). Evaluating livability and perceived values of sustainable neighborhood design: New Urbanism and original urban suburbs. Sustainable Cities and Society, 47, 101517.

Şentürer, A. (1995). Aesthetic fact in Architecture. Istanbul: İ.T.Ü. Faculty of Architecture Printing Studio.

Weber, R., Choi, Y., Stark, L. (2002). The impact of formal properties on eye movement during the perception of architecture. Journal of Architectural and Planning Research, 19(1), 57-69.

\section{Resume}

Berivan ÖZBUDAK AKÇA is currently working as an assistant professor for Dicle University Faculty of Architecture, Department of Architecture, Diyarbakır, Turkey. She graduated from Dicle University in 1999, conducted her M.Sc. in the same university in 2004. Her PhD is conducted in 2012 at Gazi University Faculty of Architecture in Ankara.

Ebru ERDOGAN received her PhD degree from the Faculty of Architecture at the University of Selcuk in 2010. She has been working as an associate professor in Selcuk University, Faculty of Fine Arts, Department of Interior Architecture and Environmental Design, Konya, Turkey. She has just completed her post- doc in the Department of Architecture at the University of Liverpool in 2020. 